\title{
Development of Students' Research Competence in the Study of the Humanities in Higher Educational Institutions
}

\author{
Alla A. Marushkevych ${ }^{1, *}$, Iryna M. Zvarych ${ }^{2}$, Oksana Y. Romanyshyna ${ }^{3}$, Nataliia M. Malaniuk ${ }^{4} \&$ Oksana L. $^{2}$ \\ Grynevych ${ }^{2}$ \\ ${ }^{1}$ Department of Pedagogy, Faculty Psychology, Taras Shevchenko National University of Kyiv, Kyiv, Ukraine \\ ${ }^{2}$ Department of Foreign Philology and Translation, Faculty of Trade and Marketing, Kyiv National University of Trade \\ and Economics, Kyiv, Ukraine \\ ${ }^{3}$ Department of Informatics and Methods of Teaching, Ternopil Volodymyr Hnatiuk National Pedagogical University, \\ Ternopil, Ukraine \\ ${ }^{4}$ Department of Higher Mathematics, Mathematical Modeling and Physics, State University of Telecommunications, \\ Kyiv, Ukraine \\ *Correspondence: Department of Pedagogy, Faculty Psychology, Taras Shevchenko National University of Kyiv, \\ 60 Volodymyrska Street, 01601, Kyiv, Ukraine. E-mail: marushkevychall@ukr.net
}

Received: December 2, 2021

Accepted: January 4, 2022 Online Published: January 17, 2022

doi:10.5430/jct.v11n1p15

URL: https://doi.org/10.5430/jct.v11n1p15

\begin{abstract}
The aim of the study was to experimentally test the effectiveness of didactic conditions for the development of students' research competence in the study of the humanities. Several complementary methods were used in the experimental study: a comprehensive test to assess the levels of research competence (S.A. Mishyn); Zamfir's Motivation of Professional Activity modified by A.N. Rean; adapted Starkey's Critical Thinking test; Simonov's Education Level technique, author's questionnaire with open-ended questions to determine the importance of research competence for students in the course of their professional education. The results of the pedagogical experiment revealed the effectiveness of the introduction of innovative forms of theoretical training (lectures and seminars) for the development of research competence in future specialists in the humanities classes. The research found the main directions of innovative experience of improving lectures, seminars as a form of education for the development of students' research competence. The research showed that it is possible to develop research competence in the process of teaching humanities depending on the types of training (theoretical, practical). It is important to organize the students' cognitive activity in the course of theoretical training, while it is necessary to apply the problem method of teaching in the practical classes. We consider the study of the problem of continuity in the development of the research culture of the individual under the conditions of continuing education as a prospect for further research.
\end{abstract}

Keywords: forms of education, future specialists, problem-based learning, professional training, research competence

\section{Introduction}

Due to a significant change in views on modern education, training is carried out on a new conceptual basis, namely in the competence approach, in which priority is not the acquisition of ready knowledge and reproductive activities of students, and independent search for new knowledge and their application in solving various personal and professional tasks.

Research competence is an important component of the specialist's professionalism, as well as a condition of its development and implementation, the readiness of the future specialist for professional activity. It is no coincidence that one of the objectives of higher education is to prepare future specialists for research activities. Involving students and teachers in fundamental research will not only preserve well-known scientific schools, but also raise a new generation of scientists. 
Research competence is the basis for the development of intellectual, communicative, design skills, develops critical thinking, creative abilities of students. Research competence should be considered a key competence. The main function of educational and research activities and its result is the intensification of students' cognitive activity, the development of the desire to learn and transform themselves and the surrounding reality according to the laws of scientific research. Research knowledge and skills is one of the main characteristics of the level of future specialist's professional maturity.

In modern socio-cultural conditions, the specialist must have the skills to navigate in problematic situations that arise in his/her professional activity, find and solve problems involving knowledge from different fields for this purpose, predict the results and possible consequences of different solutions, evaluate results and identify ways to improve action. In this regard, we can conclude that the development of research competence in future specialists is an urgent problem of research.

The aim of this study is to experimentally test the effectiveness of didactic conditions for the development of students' research competence in the study of the humanities. The main issues that arise from the research topicality and need to be addressed are the following:

1) determine the features of the organization of research work of students;

2) develop and substantiate a set of didactic conditions for the development of students' research competence in the study of the humanities;

3) explore the main directions of innovative experience in improving the forms of students' research work of in the study of the humanities.

\section{Literature Review}

As Amirova et al. (2020) noted, one of the main current goals of the countries is to achieve a high level of quality of higher education, which meets the needs of the labour market, the problems of industrial and innovative development of the country, identity and relevant international best practices in education.

The competency-based approach in education is generally understood as an approach that focuses not on the content, but on the results of education expressed in the form of competencies (Azizov \& Azizov, 2018). Research is considered one of the parameters of success of higher educational institutions worldwide (Marin et al., 2017). Therefore, it is important to develop research competence in future specialists in higher educational institutions.

Research competence is interpreted by Aleksandrova and Sluchayna (2018) as the ability to conduct independent research and provide its results. Research competence is both the main task of the development of professional and methodological competence and a means of developing other professional, cultural and general competencies (Gorshkova, 2017).

The development of student research skills at the university is associated with the improvement of skills related to critical thinking (Kartika et al., 2019), problem solving (Missingham et al., 2016) and employment skills (Bandaranaike \& Willison, 2015), especially those who become employed graduates (Willison, Sabir \& Thomas, 2017).

A recent large-scale multidisciplinary study found that graduates felt that their "general" skills were well developed through undergraduate programmes. However, employers' data indicate dissatisfaction with the general skills of graduates (Jackson, 2016). Active learning has significantly improved participants' overall research skills, as demonstrated by improved performance at the final exams, as well as individual writing and research skills (Alghamdi \& Deraney, 2018).

The success of students' research activity is largely determined by personal qualities, which include criticism and self-criticism, dissatisfaction with the results achieved, strong intelligence, strong ability to control their actions, the ability to unconventional solutions to theoretical and experimental problems, observation, honesty, openness and the courage to defend own views and positions, own vision of the problem, independence, initiative and responsibility, etc. (Vaganova et al., 2017). Research competence involves the following abilities:

- see and formulate the problem, determine the aim of the research (Supriyanto, Hartini, Syamsudin, \& Sutoyo, 2019);

- understand and justify the topicality, novelty, theoretical and practical significance of the study (Bobkova et al., 2021); 
- put forward and substantiate the hypotheses, make the plan of research (Karlibaeva, 2021);

- independently learn new research methods, acquire new knowledge;

- conduct research and present the results of their work (Predtechensky \& Fomina, 2018);

- have academic writing skills (Milad, 2017);

- critically study the references (Thongsong, Yamtim, \& Jai-Areesuthiwa, 2020).

Given the study (Albareda-Tiana, Vidal-Raméntol, Pujol-Valls \& Fernández-Morilla, 2018; Mills \& Gay, 2019), we can conclude:

- research competence of the future specialist is an integral part of professional competence;

- is a set of personality traits;

- involves certain research knowledge, skills and abilities;

- implies readiness to carry out research activities and implement research results in the practical work.

The development of research competencies is crucial to accelerate knowledge acquisition, educational innovation and successful professional development (Reyes \& Glasserman, 2020). The importance of the development of research competence urges the task of finding and implementing new effective and modern forms of its organization in the educational process. However, the teaching methods that teachers currently use seem far from reality and do not contribute to the development of research competence (Ávalos, Pérez-Escoda \& Monge, 2019).

So, based on the analysis of literature and identified problems, we formulated the hypothesis that the development of students' research competence in the study of the humanities will be effective if the educational process will involve innovative forms of theoretical training (during lectures and seminars).

\section{Methods and Materials}

The following methods were used to determine the level of future specialists' research competence: Mishyn's comprehensive test to assess the levels of research competence (Karelin, 2007); Zamfir's Motivation of Professional Activity modified by Rean (2002); adapted Starkey's Critical Thinking test (Starkey, 2004), Simonov's Education Level technique (Karelin, 2007), author's questionnaire with open-ended questions to determine the importance of research competence for students in the course of their professional education. To process the results of the study, a correlation analysis was performed using a nonparametric method of comparing two samples of Pearson's chi-squared test $\left(\chi^{2}\right)$ for independent samples. Statistical data processing was performed in SPSS 10 for Windows, Excel.

The experimental design was traditional: the studies in the experimental group were built with the involvement of certain didactic conditions, namely: introduced innovative forms of theoretical training (lectures and seminars), while studies in the control group were carried out according to traditional methods. The same teachers worked in both groups. The diagnostics was performed according to the selected criteria (cognitive, motivational-target, activity) at the end of each stage.

The subjects of the study were full-time students majoring in 012: Preschool Education, 072: Finance, Banking and Insurance, 073: Management, 081: Law, who study in the $1^{\text {st }}$ and $2^{\text {nd }}$ year of bachelor's degree. The subjects were randomly selected. The study was conducted on a voluntary basis upon the consent for personal data processing.

The experimental base of the research involved Kharkiv Humanitarian-Pedagogical Academy, South Ukrainian National Pedagogical University named after K.D. Ushynsky, V.O. Sukhomlynskyi National University of Mykolayiv, National University of Ostroh Academy. The students of the selected universities made up a general population of 375 respondents. After calculating the size of the required (representative) sample using an online calculator (with $90 \%$ confidence probability, $5 \%$ error), the size of a valid sample was 158 people. This number was the starting point for the formation of the experimental group (EG) $(n=80)$ and the control group (CG) $(n=78)$.

The experimental research took place during the study of the humanities of general professional training: Philosophy, Religious Studies, History of Ukraine, Culturology. The study was arranged in three stages during 2019-2021: the first stage - theoretical and design (2019); the second stage - experimental (2020) - a pedagogical experiment was conducted to test the research hypothesis, the didactic conditions for the development of research competence of students in the study of the humanities were theoretically and experimentally substantiated. The third stage was generalizing (September 2021) - at this stage the obtained results were compared with the expected ones and 
previous researches of scientists on the chosen problem, recommendations on the development of students' research competence were developed.

\section{Results}

The initial stage involved a survey to determine the understanding of the importance of research competence for students (Appendix A). The analysis of the survey among students found that $93 \%$ of respondents can define the term "students' research competence". They define this concept as the student's ability to research, the necessary skills and abilities to perform this type of work, as well as the ability to select, critically evaluate information and draw conclusions.

As for the main types of research activities, namely educational research and scientific research work of students, $93 \%$ of people do not consider them similar, which is the correct answer, but not everyone was able to name the forms of work.

It is important to note that $77 \%$ of surveyed students are engaged in educational research and scientific research activities. They believe that these types of work are an integral and significant part of the activities of modern educated people because they are necessary for the development of competencies, gaining new knowledge and professionalism in their field, to prepare a graduation work, during teaching practice. They also allow working with significant volumes of information, analyse it, draw conclusions; give the opportunity to fulfil themselves in research activities; improve the quality of training and cognitive interest. In student's opinion, educational and research work contributes to revealing creative abilities in the field of scientific activity and the development of research skills. It should be, however, noted that $4 \%$ of $77 \%$ of respondents who are engaged in this type of work admitted that they are engaged in this activity due to the requirements of the higher educational institution. In their opinion, a wide application of the research activity will not bring significant results, because not all students have the desire to engage in science.

The forms of educational and research activities most often used by students include: preparation of reports; preparation of term papers and diploma projects; participation in student conferences. Some students are also interested in participating in project activities; in seminars, competitions of research works; in educational and business games; in preparation of reviews and abstracts.

Answers to the question of how often students spend time on educational and research activities were also analysed. The results were as follows: $47 \%$ of surveyed students concentrate on this activity once a month, $47 \%$ - once a semester, and only $3 \%$ of students are engaged in research and development activities either once a year, or not interested in it at all. However, it should be emphasized that among the respondents there were students who prepare essays, write term papers and prepare diploma projects, but indicate that they do not participate in scientific activities.

It was found in the course of the analysis of the answers to the question: "What skills did you get while doing this type of activity?" that, according to students, the research competence today is one of the main qualities that characterize an educated person. In this activity, students, in their opinion, acquire the following skills and abilities: analyse and process a large volume of information, succinctly express their opinions and hold discussions in scientific language, write scientific papers, speak publicly, work in a team, formulate their opinion and defend their point of view. They also master an important research ability - reflection. Besides, they develop perseverance, diligence, independence, self-organization and critical thinking.

The analysis of questionnaires showed that in the real practice of higher education most teachers do not fully use the potential of the main forms of education in the development of research competence of students, only $15-20 \%$ of students are actively involved in cognitive activities during lectures and seminars. Activities aimed at the development of research competence of students are carried out during lectures sporadically, from time to time. It is not systemic, the teachers are not focused on it. This situation is due to the fact that teachers do not have enough knowledge about the pedagogical opportunities that lectures, seminars and independent work provide for the development of students' research competence, which needed further study and improvement.

The following criteria and indicators of the development of research competence in future specialists were identified for diagnostic purposes: cognitive, motivational-target, activity. The criteria were determined on the basis of scientific and psychological literature on the research topic. The cognitive criteria reflects the level of knowledge acquisition by students, motivational-target takes into account the motives of students' learning in the educational process, the activity criterion reflects the practical side of the students' research skills. 
There are three levels of research competence of future specialists (Table 1).

Table 1. Description of the Levels of Research Competence of Future Specialists

\begin{tabular}{|c|c|c|}
\hline Level & Criterion & Description \\
\hline \multirow[t]{3}{*}{ Low } & cognitive & The student learns the material at a low level. \\
\hline & motivational-target & The student is not interested in research activities. \\
\hline & activity & Partial low level of research skills. \\
\hline \multirow[t]{3}{*}{ Basic } & cognitive & $\begin{array}{l}\text { The student's theoretical knowledge is poorly realized and blurred. The student does } \\
\text { not fully learn the material. }\end{array}$ \\
\hline & motivational-target & $\begin{array}{l}\text { Situational and short-term student interest in research activities with a predominance } \\
\text { of external incentives. }\end{array}$ \\
\hline & activity & The level is characterized by the student's partial acquisition of research skills \\
\hline \multirow{3}{*}{$\begin{array}{l}\text { Educational } \\
\text { research }\end{array}$} & cognitive & The student's theoretical knowledge differs in terms of realization. \\
\hline & motivational-target & $\begin{array}{l}\text { Personal attitudes and values in the research field are stable, a conscious } \\
\text { understanding of the need to develop the research skills }\end{array}$ \\
\hline & activity & $\begin{array}{l}\text { The system of the student's research skills is established, it is basically provided by } \\
\text { the corresponding actions when performing the set research objectives. }\end{array}$ \\
\hline \multirow[t]{3}{*}{$\begin{array}{l}\text { Scientific } \\
\text { research }\end{array}$} & cognitive & $\begin{array}{l}\text { The student's theoretical knowledge differs in terms of realization, generalization, } \\
\text { breadth. }\end{array}$ \\
\hline & motivational-target & High internal need, realization, a strong desire to carry out research activities \\
\hline & activity & $\begin{array}{l}\text { Research skills are firmly established, the system includes the definition of aims and } \\
\text { objectives of the study, processing and analysis of experimental results and } \\
\text { presenting them in a scientific form. }\end{array}$ \\
\hline
\end{tabular}

Therefore, certain didactic conditions were introduced into the educational process of the experimental group, while the control group students studied according to the traditional system. After the experiment, a quiz was performed and the results were compared with the pre-experimental ones.

Analysis of the dynamics of the level of motivational-target criterion (Table 2) showed that the number of students with high levels of motivation (third and fourth) in the experimental group at the end of the experiment is significantly higher than in the control group $(65.0 \%$ and $23.0 \%$, respectively).

Table 2. Dynamics of the Development of Motivational-Target Criterion in Experimental and Control Group Students (abs./\%)

\begin{tabular}{ccccccccc}
\hline Levels & \multicolumn{2}{c}{ I } & \multicolumn{2}{c}{ I } & \multicolumn{2}{c}{ III } & \multicolumn{2}{c}{ IV } \\
\hline Groups & Initial stage & Final stage & Initial stage & Final stage & Initial stage & Final stage & Initial stage & Final stage \\
\hline EG $(\mathrm{n}=80)$ & $4 / 5.0$ & $4 / 5.0$ & $48 / 60.0$ & $24 / 30.0$ & $20 / 25.0$ & $28 / 35.0$ & $8 / 10.0$ & $24 / 30.0$ \\
CG $(\mathrm{n}=75)$ & $4 / 5.1$ & $12 / 15.4$ & $46 / 59.0$ & $48 / 61.6$ & $22 / 28.2$ & $10 / 12.8$ & $6 / 7.7$ & $8 / 10.2$ \\
\hline
\end{tabular}

With a probability of $95.0 \%$, the differences were significant $\left(\mathrm{T}_{\text {obser. }}=7.836\right.$, which is more than the critical value of $\mathrm{T}_{\text {crit. }}=7.815$ ), which means that experimental factors have a significant impact on the development of motivational-target criterion of research competence in future professionals.

Qualitative analysis revealed that the students of the experimental group began to dominate the motives directly related to research activities: "I like to look for different solutions", "I like the creative nature of professional activity" and so on. As for the students of the control group, they were dominated by motives not directly related to research activities: "the desire for self-knowledge", "the desire to obtain higher education" and others.

The results of the study on cognitive criterion (Table 3) show that while there were 14 students of the experimental group $(17.5 \%)$ at the beginning of the experiment at the "very critical" level, their number grew to 26 people (32.5\%) by the end of the experiment. This was due to a corresponding decrease in the number of students at the "rather conformism" level from 36 people at the beginning of the experiment to 16 at the end (-25.0\%). As for the control group, the number of students with a high level of critical thinking ("very critical") did not change — it was 12 
students (15.4\%) at the beginning and end of the experiment. At the same time, there is a small increase (by $7.5 \%$ ) in the number of students, differing in part in critical thinking ("rather critical"). Statistical processing showed that the difference in the experimental and control groups was significant at the level of significance of $0.05\left(\mathrm{~T}_{\text {obser. }}=7.520\right.$, with $\left.\mathrm{T}_{\text {crit. }}=5.99\right)$.

Table 3. Dynamics of the Development of Cognitive Criterion in Students of the Experimental and Control Groups (abs. $/ \%)$

\begin{tabular}{llccc}
\hline Number of students & Very critical & Rather critical & Rather conformism \\
\hline EG $(\mathbf{n}=\mathbf{8 0})$ & Initial stage & $14 / 17.5$ & $30 / 37.5$ & $36 / 45.0$ \\
& Final stage & $26 / 32.5$ & $38 / 47.5$ & $16 / 20.0$ \\
& Effect & $+12 /+150$ & $+8 /-1050$ & $-20 /-25.0$ \\
$\mathbf{W} \mathbf{G}(\mathbf{n = 7 5 )})$ & Initial stage & $12 / 15.4$ & $30 / 38.5$ & $36 / 46.1$ \\
& Final stage & $12 / 15.4$ & $32 / 41.0$ & $34 / 43.6$ \\
& Effect & $0 / 0.0$ & $+2 /+2.5$ & $-2 /-3.5$ \\
\hline
\end{tabular}

The level of the activity criterion (Table 4) was determined using a comprehensive test developed by S.A. Mishyn. Its results showed that at the end of the experiment, the number of students with high levels in the experimental group $(95.0 \%)$ was significantly higher than in the control group $(59.0 \%)$ (Table 4). Verification of the reliability of the submitted data (at the level of significance of 0.05 ) showed that the differences were statistically significant ( $\mathrm{T}_{\text {obser. }}=8.967$, with $\mathrm{T}_{\text {crit. }}=7.815$ ).

Table 4. Dynamics of the Development of Activity Criterion in Students of the Experimental and Control Groups (abs. $/ \%)$

\begin{tabular}{llllllllc}
\hline Levels & I & \multicolumn{2}{c}{ I } & \multicolumn{2}{c}{ III } & & IV \\
\hline Groups & Initial stage & Final stage & Initial stage & Final stage & Initial stage & Final stage & Initial stage & Final stage \\
\hline EG(In=80) & $3 / 3.7$ & $0 / 0.0$ & $31 / 38.8$ & $4 / 5.0$ & $39 / 48.7$ & $54 / 67.5$ & $7 / 8.8$ & $22 / 27.5$ \\
CG(n=75) & $2 / 2.7$ & $4 / 5.1$ & $30 / 38.5$ & $28 / 35.9$ & $40 / 51.3$ & $38 / 48.7$ & $6 / 7.7$ & $8 / 10.3$ \\
\hline
\end{tabular}

The study showed that purposeful work on the development of students' research competence had a positive effect on the level of education: at the end of the experiment the number of students with high levels of education in the experimental groups $(65.0 \%)$ is significantly higher than in the control groups $(23.1 \%)$ (Table 4$)$.

We used $\chi^{2}$ to determine whether there are differences in the distribution of students of the experimental and control groups after the experiment according to the levels of research competence. We formulate a hypothesis:

$\mathrm{H}_{\mathrm{o}}$ - the level of research competence after the application of innovative forms of theoretical training (lectures and seminars) in the control and experimental group is the same;

$\mathrm{H}_{1}$ - the level of research competence after the application of innovative forms of organization of theoretical training (lectures and seminars) in the experimental group is higher than in the control.

The obtained value of $\chi_{\text {emp }}^{2}=21.68$ is more critical, which for the significance of $\mathrm{p}=0.95$ and the number of degrees of freedom $\mathrm{C}=3$ is equal to $\chi^{2}=7.815$ (Table 5). Therefore, 21.68>7.815 ( $\chi_{\text {emp }}^{2} \chi^{2}$ emp) for $\mathrm{p}=0.95$. So, hypothesis $\mathrm{H}_{\mathrm{o}}$ is rejected, we accept hypothesis $\mathrm{H}_{0}$. The difference between the distributions is statistically significant.

Table 5. Dynamics of Education Levels in Students of the Experimental and Control Groups (abs./\%) (subjects: Philosophy, Religious Studies, History of Ukraine, Culturology)

\begin{tabular}{cccccccccc}
\hline Levels & \multicolumn{3}{c}{ I } & \multicolumn{2}{c}{ I } & \multicolumn{2}{c}{ III } & \multicolumn{2}{c}{ IV } \\
\hline Groups & Initial stage & Final stage & Initial stage & Final stage & Initial stage & Final stage & Initial stage & Final stage \\
\hline EG & $\underline{6}$ & $\underline{4}$ & $\underline{34}$ & $\underline{24}$ & $\underline{32}$ & $\underline{28}$ & $\underline{8}$ & $\underline{24}$ \\
$(\mathbf{I I}=\mathbf{8 0})$ & 7.5 & 5.0 & 42.5 & 30.0 & 40.0 & 35.0 & 10.0 & 30.0 \\
$\mathbf{C G}$ & $\underline{5}$ & $\underline{12}$ & $\underline{32}$ & $\underline{48}$ & $\underline{32}$ & $\underline{12}$ & $\underline{9}$ & $\underline{6}$ \\
$(\mathbf{n}=\mathbf{7 5})$ & 6.4 & 15.4 & 41.0 & 61.5 & 41.0 & 15.4 & 11.6 & 7.7 \\
\hline
\end{tabular}




\section{Discussion}

The level of research competence after the application of innovative forms of theoretical training (lectures and seminars) in the control and experimental groups became higher than in the control group. So, purposeful work on the development of students' research competence has a positive effect on the level of research competence and the level of learning on the subjects in which the experimental work was conducted.

One of the features of the organization of research work of students is that it is most often carried out in senior courses, as Boltianska (2021) noted. In our study, experimental work was carried out in the course of studying the subjects of the humanities course which are mandatory for all students.

However, the development of research competence throughout the educational process in the educational institution involves solving problems of varying levels of complexity and allows for gradual, consistent development of research skills, including in the study of the humanities, which is also confirmed by Glazunova, Kuzminska, Morze and Voloshyna (2019). It was determined that when involving students in research work, it is important to take into account their individual psychological characteristics, which include the level of intelligence, creativity, learning motivation, high self-esteem.

Current research shows that teachers often do not indicate the forms and means of developing fundamental research skills in practical curricula (Torres, 2018). The main directions of the innovative experience of improving the lecture as a form of organization of education for the development of students' research competence were identified in the course of the research. In the course of the experiment, the lecture was attributed a problematic nature; enhanced interactivity, which provides dialogic interaction of participants in the learning process, productive learning activities of students. The integration of the lecture with other forms of learning was ensured and developmental opportunities of traditional lectures were enhanced through the use of cognitive activity enhancing techniques (professional orientation, reliance on personal experience, emotional presentation, combination of words and clarity, etc.). This form is also substantiated in Varga (2020).

Comparison of the dynamic structure of activities and the structure of lectures as a form of organization of learning allowed stating that all stages of research activities can be equally incentivized motivationally, what is confirmed by the research of Oliynyk (2018). The lecture has the greatest opportunities to provide an indicative phase and a programming phase. The last phase — control and correction — is provided to a lesser extent. As for the programming phase, in which supporting the desire to achieve the goal is the main motivational task, the role of the teacher, his/her personal and professional qualities, ability to ask rhetorical and problematic questions, give convincing examples from life experience to confirm theoretical statements, etc. is important at this stage.

The seminars provide pedagogical opportunities in the development of students' research competence because they objectively involve independent active work of students both in the process of preparation (work on primary sources and other literature, etc.) and in the process of their delivery (reporting, asking questions, providing evaluative judgments, etc.). However, the implementation of innovative forms, as Shkabarina et al. (2021) noted, requires compliance with a number of psychological and pedagogical conditions: the optimal level of complexity of issues and tasks; their practical orientation, connection with the surrounding real and virtual reality; the use of techniques, methods and tools that help create a positive emotional background; ensuring freedom for creativity; individualization of tasks and assignments; organization of meaningful communication and exchange of views; emphasizing the special value of the learner's point of view, unique vision of the situation.

Didactic conditions for strengthening the developmental potential of problem-based forms of seminars (seminar-discussion, seminar-research, seminar-dispute, expert seminar, seminar-game) in the development of students' research competence have been developed. The main requirements for the applied means of strengthening the research potential of the seminars are:

a) ensuring the involvement of all students in educational activities due to the mandatory combination of individual and team work in their structure;

b) ensuring a high degree of cognitive independence of students due to the dominance of mental activities analysis, comparison, analogy, reliance on personal experience, ideas, problem and rhetorical questions, presentation and justification of the results of students' own individual and group activities, etc.;

c) solving professional, everyday life and personal problems.

The study showed some specifics in the realization of the opportunities of problem-based learning (Kryvylova, 2017) for the development of students' research competence depending on the types of training (theoretical, practical). In 
the process of theoretical learning, the specifics of problem-based learning is that students are mainly involved in search to find answers to problem questions, problem-solving. In order to strengthen the research potential of such tasks and assignments, they should become practically and professionally oriented, while the structure of educational activities should be built depending on the level of problems and taking into account its dynamic component and motivational substructure. The organization of students' independent project activities, which should be strengthened through interdisciplinary links and links with real life and future professional practice, is important in the development of research competence.

Besides, research competencies need to take into account those that allow the development of academic reading and writing in university students, as this is an area that requires considerable attention from the education field (Castillo-Martínez \& Ramirez-Montoya, 2021).

\section{Conclusions}

Graduates of the modern system of higher education must have competencies that would allow them to find innovative solutions to emerging problems, set and solve new problems. The research component is becoming increasingly important in the structure of readiness of the future specialist for future socio-professional activities. The study allowed determining that the development of students' research competence in the study of the humanities will be effective through the introduction of innovative forms of theoretical learning (lectures and seminars).

It is determined that when teaching the humanities, it is possible to develop research competence depending on the types of training (theoretical, practical). In the course of theoretical training (lectures and seminars) it is important to organize cognitive activities taking into account the levels of students' research competence; motivate students for research work, apply interactivity; emphasize the personal and professional significance of the educational problems to be solved.

Research materials can be used by teachers of the humanities to improve teaching materials to strengthen their research orientation; by teachers of higher educational institutions and vocational schools, specialists of the system of advanced training of pedagogical staff.

We consider the study of the impact of research activities on the quality of professional training of graduates of educational institutions, as well as the study of the problem of continuity in the development of student's research culture in the context of continuing education to be the prospects for further research.

\section{References}

Albareda-Tiana, S., Vidal-Raméntol, S., Pujol-Valls, M., \& Fernández-Morilla, M. (2018). Holistic approaches to develop sustainability and research competencies in pre-service teacher training. Sustainability, 10(10), 3698.

Aleksandrova, N. N., \& Sluchayna, L. (2018). Formation of research competence of future economists in the process of mastering foreign languages. Journal of Advanced Research in Law and Economics, 9(8/38), 2517-2529.

Alghamdi, A. K. H., \& Deraney, P. (2018). Teaching research skills to undergraduate students using an active learning approach: a proposed model for preparatory-year students in Saudi Arabia. International Journal of Teaching and Learning in Higher Education, 30(2), 184-194.

Amirova, A., Jeksembekova, M. I., Taubayeva, G. Z., Zhundibayeva, T. N., \& Uaidullakyzy, E. (2020). Creative and research competence as a factor of professional training of future teachers: Perspective of learning technology. World Journal on Educational Technology: Current Issues, 12(4), 278-289. https://doi.org/10.18844/wjet.v12i4.5181

Ávalos, C., Pérez-Escoda, A., \& Monge, L. (2019). Lean Startup as a learning methodology for developing digital and research competencies. Journal of New Approaches in Educational Research (NAER Journal), 8(2), 227-242. https://doi.org/10.7821/naer.2019.7.438

Azizov, S. Y., \& Azizov, A. A. (2018). Competence approach in education. Scientific notes of Khujand State University. Academician B. Gafurov. Humanities, 3(56), 164-168.

Bandaranaike, S., \& Willison, J. (2015). Building capacity for work-readiness: bridging the cognitive and affective domains. Asia-Pacific Journal of Cooperative Education, 16(3), 223-233.

Bobkova, A., Vitvitskyi, S., Zakharchenko, A., Nikolenko, L., \& Katrych, A. (2021, May). Formation of scientific research competencies of law students. In V. Lubkina, G. Strods, \& O. Vindaca (Eds.), Society. Integration. 
Education. Proceedings of the International Scientific Conference (Vol. 1, pp. 38-49). Rēzekne, Latvia: Rēzeknes Tehnologiju akadēmija. https://doi.org/10.17770/sie2021vol1.6484

Boltianska, N. I., (2021). Technologies of scientific research to technical service: a course of lectures. Melitopol, Ukraine: Lyuks.

Castillo-Martínez, I. M., \& Ramirez-Montoya, M. S. (2021). Research competencies to develop academic reading and writing: a systematic literature review. Frontiers in Education, 5, 576961. https://doi.org/10.3389/feduc.2020.576961

Glazunova, O. G., Kuzminska, O. G., Morze, N. V., \& Voloshyna, T. V. (2019). Using scientific e-conferences for the research competence development: students' point of view. Information Technologies and Learning Tools, 72(4), 168-181. https://doi.org/10.33407/itlt.v72i4.2951

Gorshkova, O. O. (2017). Preparing students for research activities in the context of competence-oriented engineering education. Journal of Fundamental and Applied Sciences, 9(S2), 1445-1467. https://doi.org/10.4314/jfas.v9i2s.853

Jackson, D. (2016). Skill mastery and the formation of graduate identity in bachelor graduates: Evidence from Australia. Studies in Higher Education, 41(7), 1313-1332. https://doi.org/10.1080/03075079.2014.981515

Karelin, A. (2007). Great Encyclopedia of psychological tests. Moscow: Eksmo.

Karlibaeva, G. E. (2021). Forming research competencies in future physics teachers. Berlin Studies Transnational Journal of Science and Humanities, 1(1.5), 102-109. https://doi.org/10.5281/zenodo.5215869

Kryvylova, O. (2017). Features of the use of problem-based teaching methods in psychological and pedagogical training of future teachers of vocational schools. ScienceRise: Pedagogical Education, 3(11), 20-26. https://doi.org/10.15587/2519-4984.2017.97208

Marin, E., Iftimescu, S., Ion, G., Stingu, M., \& Proteasa, C. (2017). Academic managers` perspective on research management in higher education institutions across Romania. In: J. Domenech i Soria, M. Cinta Vincent Vela, E. de la Poza, \& D. Blazquez (Eds.), Proceedings of the 3rd International Conference on Higher Education Advances (pp. 1185-1192). Valencia, Spain: Valencia Polytechnic University. https://doi.org/10.4995/HEAD17.2017.6713

Milad, M. (2017). Blended learning approach: integrating reading and writing research skills to improve academic writing. Arab Journal of Applied Linguistics, 3(3), 23-55.

Mills, G. E., \& Gay, L. R. (2019). Educational research: Competencies for analysis and applications, $12^{\text {th }}$ edition. New York, NY: Pearson.

Missingham, D., Cheong, M., Serfas, L., Phadke, D., \& Symes, M, (2016). Validating student-led learning initiatives in problem solving: a cross institutional case study. In: Proceedings of the 27th Annual Conference of the Australasian Association for Engineering Education (pp. 598-609). Lismore: Southern Cross University. Retrieved from https://search.informit.org/doi/book/10.3316/informit.9780994152039

Oliynyk, I. V. (2018). Motivational component of the formation of research competence in future doctors of philosophy in graduate school (Doctoral dissertation, Alfred Nobel University, Dnipro, Ukraine). Retrieved from http://ir.duan.edu.ua/handle/123456789/1461

Predtechensky, B., \& Fomina, M. (2018). Independent work of students as the leading form of educational process organization at the university. Turkish Online Journal of Design Art and Communication, 8(S3), 45-48. https://doi.org/10.7456/1080MSE/006

Rean, A.A. (2002). Psychology and pedagogy. Saint Petersburg: Piter.

Reyes, C. E. G., \& Glasserman, L. (2020). Research competencies mediated by technologies: A systematic review of the literature in Scopus. Preprints, 2020, 2020070125. https://doi.org/10.20944/preprints202007.0125.v1.

Shkabarina, M., Vitiuk, V., Surzhuk, T., Iovkhimchuk, N., \& Klochko, T. (2021). The effectiveness of the implementation of interactive methods in the distance learning system of future primary school teachers. Laplage Em Revista, 7(Extra-D), 332-342. https://doi.org/10.24115/S2446-622020217Extra-D1105p.332-342

Starkey, L. (2004). Critical thinking skills success. New York, NY: Learning Express, LLC. 
Supriyanto, A., Hartini, S., Syamsudin, S., \& Sutoyo, A. (2019). Indicators of professional competencies in research of guidance and counseling teachers. Counsellia: Jurnal Bimbingan dan Konseling, 9(1), 53-64. http://doi.org/10.25273/counsellia.v9i1.3927

Thongsong, B., Yamtim, V. \& Jai-Areesuthiwa, A. (2020). Research competency enhancement process based on knowledge management procedures for developing routine to research of support staff at Thaksin university. Kasetsart Journal of Social Sciences, 41(2), 441-448. https://doi.org/10.34044/j.kjss.2020.41.2.15

Torres, L. (2018). Research skills in the first-year biology practical-are they there?. Journal of University Teaching and Learning Practice, 15(4), 3. https://doi.org/10.53761/1.15.4.3

Vaganova, O. I., Lapshova, A. V., Kutepov, M. M., Tatarnitseva, S. N., \& Vezetiu, E. V. (2020). Technologies for organizing research activities of students at the university. Amazonia Investiga, 9(25), 369-375.

Varga, N. (2020). Forms and methods of formation of research competence of the future teacher of the US higher education in master's degree. Scientific Bulletin of Uzhhorod University. Series: "Pedagogy. Social work», 2(47), 33-38. https://doi.org/10.24144/2524-0609.2020.47.33-38

Willison, J., Sabir, F., \& Thomas, J. (2017). Shifting dimensions of autonomy in students. Research and employment. Higher Education Research \& Development, 36(2), 430-443. https://doi.org/10.1080/07294360.2016.1178216

\section{Appendix A}

\section{The level of students' research competence questionnaire}

1. What do you mean by "research competence"?

2. Name the main forms of research.

3. Do you do educational research and scientific research work?

4. Name the forms of research work.

5. How often do you spend time on research?

6. What skills did you gain during the research work?

7. Do you do research work during lectures and practical classes?

\section{Copyrights}

Copyright for this article is retained by the author(s), with first publication rights granted to the journal.

This is an open-access article distributed under the terms and conditions of the Creative Commons Attribution license (http://creativecommons.org/licenses/by/4.0/). 